\title{
The Effects of Intellectual Property Rights Violations on Economic Growth
}

\author{
Patrick G. McLennan ${ }^{1}$, Quan V. Le ${ }^{2}$ \\ ${ }^{1}$ University of Denver, Denver, USA \\ ${ }^{2}$ Department of Economics, Seattle University, Seattle, USA \\ E-mail: lequ@seattleu.edu,pmclenna@du.edu \\ Received December 20, 2011; revised March 2, 2011; accepted April 3, 2011
}

\begin{abstract}
This paper examines the relationship between intellectual property rights (IPRs) and the growth rate of per capita GDP during the period 1996-2006 in a sample 71 countries. Using software piracy data as a proxy for IPR violations, we find that countries with increasing rates of software piracy have lower growth rates. We also find that states with strong commitments to enact policies to protect intellectual property rights are able to achieve higher growth rates.
\end{abstract}

Keywords: Intellectual Property Rights, Software Piracy, Economic Growth

\section{Introduction}

This paper considers intellectual property rights (IPRs) a fundamental institution for economic growth. We also view the state as equally important because implementing laws to protect property cannot be provided through private means; enforcement must come from a legitimate source. Previous studies focus on the ability of the state to produce and distribute IPR protection [1], or its inability to enforce them [2]. This paper explores the role of IPR violations on economic growth. Specifically, it focuses on the rates at which software piracy is increasing, which demonstrate deteriorations in IPR protection. We hypothesize that countries with rising rates of software piracy exhibit decreasing growth rates of per capita GDP.

According to the Business Software Alliance (BSA) and International Data Corporation (IDC), software piracy has many negative economic consequences. IDC and BSA's study revealed that "decreasing piracy by 10 percentage points over four years would add more than 2.4 million new jobs and almost $\$ 70$ billion in tax revenues to local governments worldwide. Most of that new employment and most of an additional $\$ 400$ billion in GDP would be added to local economies (p. 6) [3]. Thus, the effects of intellectual property rights violations on economic growth are quite clear. Countries with higher rates of IPR violations tend to have lower growth rates. In other words, when business is disrupted, and governments ignore, or take away the ability to produce legiti- mate capital, people become less productive, leading to lower economic growth.

We test the connection between GDP per capita growth and software piracy, along with a governance indicator in a sample of 71 countries from 1996 to 2006. Although the period is more limited than previous studies, this indicator examines a period in which the world has seen increased market integration, especially in the technology industries. The IDC and BSA [3] state that "the issues in dealing with PC software piracy in emerging markets remain-from a rapid influx of new PC users in the consumer and small business sectors, to increased availability of pirated software over the Internet and difficult enforcement and education over sometimes sprawl- ing geographies (p. 1)". Thus, the rise of economic powers in East Asia, along with the ongoing importance of petro-states in the Middle East, gives further context for the study's importance. Given the fact that most previous studies have focused on the distribution of IPRs or the bureaucratic inefficiencies associated with business growth, this paper gives a unique insight into the role of property rights violations and its effects on economic growth.

Given that previous studies have focused on the distribution of IPRs or the bureaucratic inefficiencies associated with business growth, this paper provides a unique insight into the role of property rights violations and its effects on economic growth. Software piracy has a negative impact on economic growth because, according to 
the IDC, "for every $\$ 1$ in software sold, there is at least another \$1.25 in services sold in design, install, customize and support that software. That software and those additional services then drive approximately $\$ 1$ of channel revenue. Most of the additional services or channels revenue goes to local firms (p. 6) [3]. Countries that have significant IPR violations cannot take advantage of the revenues generated by obtaining legitimate software. Further, the global picture indicates that software piracy remains a global issue affecting both developed world and emerging countries. According to IDC and BSA [3], the legitimate software market in developed countries is almost 10 times the size of that in emerging countries; however, the losses from software piracy are merely double. Thus, software piracy has a negative impact on economic growth in both developed countries and emerging countries.

The paper is organized as follows. Section 2 provides a brief overview of the literature. The data and measures used in the empirical analysis are described in Section 3 and the results are discussed in Section 4 . Section 5 offers the concluding remarks with a discussion on IPRs in China.

\section{A Brief Overview of the Literature}

In his earlier work on property rights and economic growth, Leblang [4] shows that countries that protect property rights grow faster than those that do not. Leblang [4] uses credit access to the private sector as a proxy for property rights because it "represents the scope of and support for free enterprise (p. 12)”. Drawing on the earlier work of Goldsmith [5] he explores the presence of democracy, assuming that democratic states have more protection of property rights, and, thus, grow faster. Leblang [4] finds a strong correlation among property rights, democracy and growth. However, this attempt to correlate protection of property rights with democratic political regimes falls short. He even claims it as a "fundamental mistake” (p. 18) in current literature, stating that democracy may not ensure property rights, and property rights may not insure democracy. That is, other types of government's may provide adequate property rights; his results aren't only democratic phenomena.

Similarly, Svensson's [6] study finds that countries with unstable governments have few incentives to protect property rights. Political instability reduces the need for incumbents to prepare future regimes for economic development. Park and Ginarte [7] write that IPRs affect growth by encouraging firms to accumulate more inputs, and conduct research and development. Clague et al. [8] introduces the variable of contract-intensive money to explore private entities' willingness to invest. They find that economic gains are made when a government protects private economic actions. Keefer and Knack [2] take this further and look at the role of social polarization and government on property rights. They find that increased social polarization does not affect investor confidence directly; it influences the policy process, which is ultimately responsible for the distribution of property rights. However, they do contend that property rights may have a bigger impact on investment and growth than extreme political instability, including political violence, revolutions, coups, and revolutions.

In the FDI literature, Markusen [9] explains that multinational companies will gain from property rights if they switch their production to a different country, but this may be bad for economic growth if it crowds out any existing production in the same industry. Javorcik [10] finds that weak IPRs discourages foreign investors from innovating. Furthermore, this appears to be more apparent in technology-intensive industries. Glass and Saggi [11] argue that stronger IPRs benefit stable and developed economies, but imitation and copying waste useful economic resources. Claessens and Laeven [12] argue that weak property rights in a country with "poorly developed financial systems (p. 2431)” make it hard for firms to obtain outside financing, limiting growth. Falvey et al. [13] finds that IPRs have an ambiguous impact on economic growth. They find that IPRs appear to be beneficial for high and low income countries, but IPRs do not matter for middle-income countries where a market niche may be in product imitation. In other words, violating property rights may help growth for a period of development.

Other works are skeptical or completely against IPRs. More recently, Lerner [1] explores the role of the state and finds that there is little positive impact of protecting patents on innovation. He focuses on the number of patents demanded and negates specific processes limiting these activities - violations and institutional quality, which can discourage or encourage production. Boldrin and Levine [14] argue that protecting innovative activities is important for the first units of "discovery," but in the long-run, protecting intellectual property is damaging because of diminishing returns and the extent to which less developed economies can imitate and copy.

This paper provides a unique way of studying the effects of property rights on economic growth by utilizing software piracy as a proxy for IPRs violations.

\section{Data}

Software piracy data is obtained from BSA and IDC's Global Software Piracy Study 2006. IDC covers all packaged software that runs on personal computers, including 
laptops, desktops, business applications, consumer applications, operating system, databases, etc. [3]. The following formula reflects the method IDC applied to measure piracy rates: 1 ) determine how much packaged software was put into use; 2) determine how much packaged software was paid for or legally acquired; 3) subtract one from the other to get the amount of pirated software; and 4) determine the piracy rate as the percentage of total software installed that was not paid for or legally acquired [3].

The change in the piracy rates, $\triangle P I R A C Y$, is used to measure IPRs violations. This approach has a desirable feature for this study. While the total worldwide weighted average piracy rate is $35 \%$, the median piracy rate is $62 \%$ in 2006, implying that half of the countries in the BSA and IDC study have a piracy rate of $62 \%$ or higher [3]. However, some countries experienced significant piracy rates drop, while others experienced rates increase. By differentiating we can observe these changes. A positive number implies increasing rates of piracy, while a negative number indicates decreasing rates of piracy. Table 1 groups the countries into quintiles depicting the change in piracy rates. The table reveals that many developed countries and emerging markets, such as China, India, and South Korea appear to have declining rates of piracy. China is a particularly striking example of a declining piracy rate. Between 2003 and 2006, the average annual economic growth rate in China is $9.58 \%$, and the average

Table 1. Change in piracy rates.

\begin{tabular}{|c|c|c|c|c|}
\hline \multicolumn{2}{|c|}{ Increasing rates of property rights violations } & & \multicolumn{2}{|c|}{ Decreasing rates of property rights violations } \\
\hline Highest & Medium & Low & Negative & Significantly negative \\
\hline 5 to 14 & 2 to 4 & 0 to 1 & -1 to -3 & -4 to -10 \\
\hline Chile & Argentina & Algeria & Australia & China \\
\hline Colombia & Cameroon & Botswana & Austria & Costa Rica \\
\hline Panama & El Salvador & Cote d'Ivoire & Belgium & Egypt \\
\hline \multirow[t]{28}{*}{ Venezuela } & Guatemala & France & Brazil & Finland \\
\hline & Honduras & Hong Kong & Bulgaria & Ireland \\
\hline & Italy & Hungary & Canada & Japan \\
\hline & Peru & Kenya & Cyprus & Jordan \\
\hline & Portugal & Mexico & Denmark & Kuwait \\
\hline & Spain & Nicaragua & Ecuador & Netherlands \\
\hline & Uruguay & Senegal & Estonia & Morocco \\
\hline & Zimbabwe & Thailand & Germany & Romania \\
\hline & & Zambia & Greece & Singapore \\
\hline & & & India & Switzerland \\
\hline & & & Indonesia & \\
\hline & & & Israel & \\
\hline & & & Latvia & \\
\hline & & & Malaysia & \\
\hline & & & Mauritius & \\
\hline & & & New Zealand & \\
\hline & & & Nigeria & \\
\hline & & & Norway & \\
\hline & & & Oman & \\
\hline & & & Paraguay & \\
\hline & & & Philippines & \\
\hline & & & South Africa & \\
\hline & & & South Korea & \\
\hline & & & Sweden & \\
\hline & & & Tunisia & \\
\hline & & & Turkey & \\
\hline & & & United Kingdom & \\
\hline & & & United States & \\
\hline
\end{tabular}

Note: Change in Piracy Rates, $\triangle P I R A C Y=P I R A C Y$ RATE $2006-P I R A C Y R A T E_{2003}$. 
piracy rate is $87.5 \%$ - a very astonishing level. However, the change in the rate of piracy is -10 (a decrease of ten percentage points). Given the IDC and BSAs data regarding the economic benefit to decreasing software policy, it is more logical to attribute such high economic growth to China's ability to decrease IPRs violations rather than to only look at the country's very high piracy rates.

Following Barro [15], we control for initial GDP per capita (GDPPC), and secondary school-enrollment rates (SECEDU). According to the convergence hypothesis, initial GDP per capita is expected to have a negative sign. Human capital, proxied by secondary school-enrollment rates, contributes positively to growth in the endogenous growth model. Human capital is expected to have a positive sign. Data for initial GDP per capita and secondary school-enrollment rates are taken from the World Development Indicators [16].

The cost of software is only one factor driving software piracy. The strength of intellectual property laws, and the effectiveness of the institutions enforcing IPRs also contribute to the reduction of IPR violations. Strong institutions and good governance assures investors more assurance that their ability to be innovative is protected. In order to control for differences in institutional quality, we use the Kaufmann, Kraay, and Mastruzzi's (KKM) [17] governance dataset. KKM [17] compute aggregate perceptions of governance from 33 data sources provided by 30 different organizations and classify them into six indicators. Each indicator refers to a different dimension of governance: government effectiveness, regulatory quality, rule of law, control of corruption, political voice and accountability, and absence of political violence. Globerman and Shapiro [18] argue that these indicators are highly correlated with each other. Thus, it is very difficult to use them all in a single regression equation. To overcome this problem, we employ factor analysis to extract the first principal component of the six indicators of governance. We denote this aggregate measure as GOVERNANCE. Tables $\mathbf{2}$ and $\mathbf{3}$ present descriptive statistics and correlations matrix.

\section{Empirical Results}

Ordinary least squares (OLS) estimates are reported in Table 4 with the annual growth rate of per capita GDP taken from the World Development Indicators [16] as a dependent variable. Equation (1) in Table 4 shows that $\triangle P I R A C Y$ has a negative significant effect on growth as predicted, suggesting that countries with increasing rates of IPRs violations have lower rates of economic growth. Equation (1) explains about 8\% of the variation in economic growth. In Equation (2) we include initial per capita GDP, secondary school-enrollment rates, and governance in the regression analysis. The estimated coefficient in initial per capita GDP is negative and highly significant,

Table 2. Descriptive statistics.

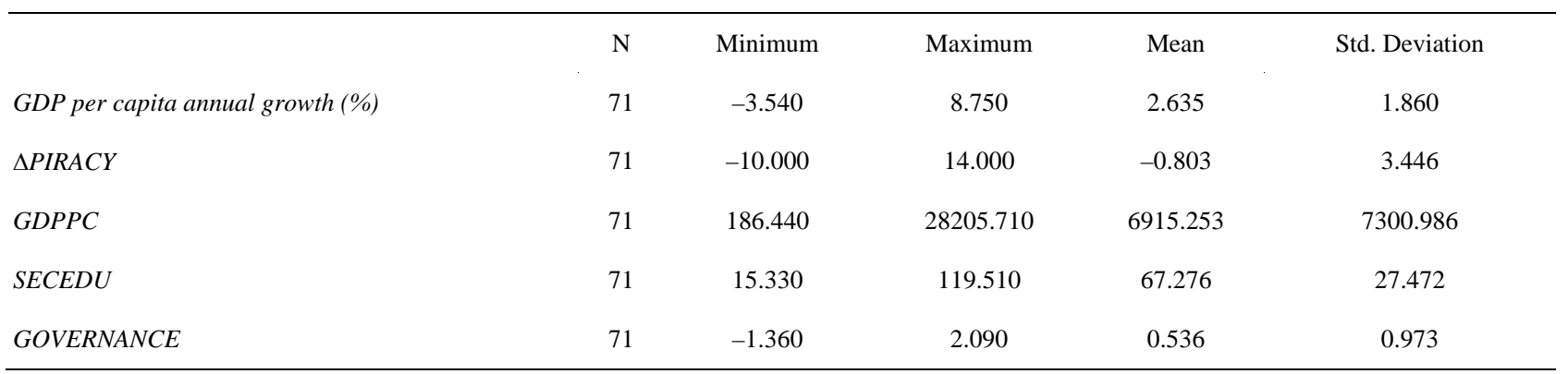

Table 3. Correlations matrix.

\begin{tabular}{|c|c|c|c|c|c|}
\hline & $\begin{array}{l}\text { GDP per capita annual } \\
\text { growth (\%) }\end{array}$ & $\square P I R A C Y$ & $G D P P C$ & SECEDU & GOVERNANCE \\
\hline GDP per capita annual growth (\%) & 1.000 & $-0.300^{*}$ & -0.177 & 0.164 & 0.113 \\
\hline$\triangle P I R A C Y$ & $-0.300^{*}$ & 1.000 & -0.207 & -0.153 & -0.196 \\
\hline$G D P P C$ & -0.177 & -0.207 & 1.000 & $0.702^{* *}$ & $0.779^{* *}$ \\
\hline SECEDU & 0.164 & -0.153 & $0.702^{* *}$ & 1.000 & $0.807^{* *}$ \\
\hline GOVERNANCE & 0.113 & -0.196 & $0.779^{* *}$ & $0.807^{* *}$ & 1.000 \\
\hline
\end{tabular}

Notes:* Pearson Correlation is significant at the 0.05 level (2-tailed), ** Pearson Correlation is significant at the 0.01 level (2-tailed). 
Table 4. Regression results.

\begin{tabular}{|c|c|c|c|c|c|c|}
\hline & $\begin{array}{l}(1) \\
\text { OLS }\end{array}$ & $\begin{array}{l}(2) \\
\text { OLS }\end{array}$ & $\begin{array}{l}(3) \\
\text { OLS }\end{array}$ & $\begin{array}{l}(4) \\
I V^{a}\end{array}$ & $\begin{array}{l}(5) \\
I^{b}\end{array}$ & $\begin{array}{l}(6) \\
I^{c}\end{array}$ \\
\hline CONSTANT & $\begin{array}{l}2.505^{* * *} \\
(11.497)\end{array}$ & $\begin{array}{c}1.790 * * * \\
(2.681)\end{array}$ & $\begin{array}{c}1.769 * * * \\
(2.823)\end{array}$ & & & \\
\hline$\triangle P I R A C Y$ & $\begin{array}{c}-0.162 * * * \\
(-2.613)\end{array}$ & $\begin{array}{c}-0.181^{* * *} \\
(-3.285)\end{array}$ & $\begin{array}{c}-0.118^{* *} \\
(-2.133)\end{array}$ & $\begin{array}{c}-0.952 * * * \\
(-2.773)\end{array}$ & $\begin{array}{l}-0.578 * \\
(-1.908)\end{array}$ & $\begin{array}{l}-0.292^{*} \\
(-1.824)\end{array}$ \\
\hline GDPPC & & $\begin{array}{c}-0.000201 * * * \\
(-4.857)\end{array}$ & $\begin{array}{c}-0.000193 * * * \\
-4.936)\end{array}$ & $\begin{array}{l}-0.844 \\
(-1.282)\end{array}$ & $\begin{array}{c}-0.0001 \\
(0.254)\end{array}$ & $\begin{array}{c}-0.0005 * * \\
(-2.036)\end{array}$ \\
\hline SECEDU & & $\begin{array}{c}0.026^{* *} \\
(2.209)\end{array}$ & $\begin{array}{c}0.024^{* *} \\
(2.196)\end{array}$ & $\begin{array}{c}-0.727 \\
(-0.756)\end{array}$ & $\begin{array}{l}-0.089 \\
(-0.801)\end{array}$ & $\begin{array}{c}0.012 \\
(0.192)\end{array}$ \\
\hline GOVERNANCE & & $\begin{array}{l}0.068^{*} \\
(1.813)\end{array}$ & $\begin{array}{c}0.784^{* *} \\
(2.219)\end{array}$ & $\begin{array}{l}1.141^{*} \\
(1.861)\end{array}$ & $\begin{array}{l}1.203 \\
(.672)\end{array}$ & $\begin{array}{l}3.267^{* *} \\
(2.135)\end{array}$ \\
\hline CHINA & & & $\begin{array}{c}4.997 * * * \\
(3.153)\end{array}$ & & & \\
\hline No. of observations & 71 & 71 & 71 & 50 & 50 & 50 \\
\hline Adjusted $\mathrm{R}^{2}$ & 0.08 & 0.30 & 0.39 & 0.19 & 0.05 & 0.14 \\
\hline
\end{tabular}

Notes: the dependent variable is GDP per capita annual growth (\%). t-statistics are in parentheses. ***, **, * statistically significant at the $1 \%$, $5 \%$, $10 \%$ levels,

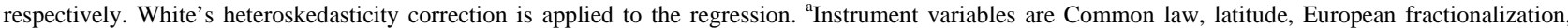
language fractionalization, and lagged values of economic indicators. ${ }^{\mathrm{b}}$ Instrument variables are UK colony, latitude, European fractionalization, language fractionalization, and lagged values of economic indicators. ' Instrument variables are Spanish colony, latitude, European fractionalization, language fractionalization, and lagged values of economic indicators.

confirming the convergence hypothesis. The growth rate of per capita GDP is positively related to initial human capital as hypothesized, suggesting that countries with greater initial stocks of human capital experience higher rate of introduction of new products and ideas and thereby tend to grow faster. The estimated coefficient of GOVERNANCE, is positive and significant, indicating that good governance, especially protecting property rights, assures investors that their innovations and products are protected under the law. More importantly, $\triangle P I R A C Y$ continues to have a negative significant effect on growth. Equation (2) explains about $30 \%$ of the variation in economic growth.

Recognizing that China is an exceptional phenomenon, a dummy variable for China is included in Equation (3). The result indicates that $\triangle$ PIRACY continues to have a negative significant effect on growth, while the other control variables remain robust with the intuitive signs. With the inclusion of a dummy variable for China, Equation (3) explains about $39 \%$ of the variation in economic growth.

We recognize a potential problem that $\triangle P I R A C Y$ is an endogenous variable, thus OLS regression is biased. Countries are not exogenously endowed with the institutions that promote IPRs. Indeed, IPR protection is determined endogenously, depending on the type of law that governs the country. Countries with a Common law legal system rely on the decisions of courts to frame laws. Property rights violations are adjudicated through a court, which uses precedent to make a decision. In Civil law legal systems, laws are enacted by through the legislative process. Previous concepts pertaining to the new statute are included unless there is a reversal in the law. According to Levine [19], Common law states are argued to protect property rights more efficiently because the legal framework tends "to adapt more efficiently to the changing contractional needs of an economy than legal systems that adhere rigidly to formalistic procedures and codified laws (p. 65)" found in Civil law legal systems. There are 19 Common law states and 52 Civil law states in our sample. The average piracy rate for Common law states is $53 \%$, while the average piracy rate for Civil law states is $60 \%$. Furthermore, the average change in the rate of piracy is -1.2 (a decline of 1.2 percentage points) for Common law states compared to -0.6 for Civil law states, confirming that Common law legal system is better at protecting property rights than Civil law legal system. We also employ other instrument variables to confirm the robustness of the results. These include past colonial relations-UK colony and Spanish colony.

Instrumental variable (IV) estimation can be used to account for endogeneity, given the appropriate instruments. Before we proceed with IV estimation, we perform a Hausman test for endogeneity to show whether 2SLS is necessary. The test marginally rejects the hypothesis of consistent OLS estimates, suggesting that it is a good idea for us to report both OLS and IV estimates. Our choices of instruments are Common law, UK colony, Spanish colony, Western European influence (European fractionalization), language fractionalization, and macroeconomic initial conditions (investment, FDI, and inflation). The instruments are positively related with 
IPRs. Equations (4-6) report the result indicating that $\triangle P I R A C Y$ has a negative and significant effect on economic growth.

In summary, the results in Table 4 reveal that countries with increasing rates of software piracy have lower rates of per capita growth, suggesting that IPRs violations are impediments to economic growth.

\section{Concluding Remarks}

This paper demonstrates that the effects of IPRs violations on economic growth are significantly robust. Countries with increasing rates of property rights violations tend to have lower growth rates. In other words, when the means of production are disrupted, ignored, or even taken away, people become less productive, which in turn leads to lower economic growth. The results also show countries with strong governance to enact policies to protect property rights exhibit increasing growth. Thus, governments must introduce strong policies aiming at protecting IPRs to promote economic growth.

China is a good example for other emerging markets to follow. The Chinese government realizes that one of the greatest barriers for MNCs to successfully doing business in China and for Chinese companies to successfully competing in the global economy is its stance on IPRs. As MNCs continue to invest in China, and as local companies in China increasingly become multinational; the risks of using pirated software will encourage the use of legitimate software.

China's piracy rate has dropped 10 points since 2003, a result of stronger enforcement actions and government-driven education programs as well as engaging in distribution agreements with original equipment manufacturers (OEMs). For instance, the government has mandated that PC OEMs only ship PCs with legitimate software. The government also conducts raids in numerous regions including Beijing, Shanghai, Xian, and Shenyang. In addition, the government continues its efforts to endorse legal use of software in government agencies and state-owned enterprises. The efforts have been economically rewarded. According to IDC, since 2003 China has added more than 800000 jobs to its IT sector, of which IDC attributes 220000 to lower software piracy.

\section{References}

[1] J. Lerner, "The Empirical Impact of Intellectual Property Rights on Innovations: Puzzles and Clues,” American Economic Review: Papers and Proceedings, Vol. 99, No. 2, 2009, pp. 343-348. doi:10.1257/aer.99.2.343

[2] P. Keefer and S. Knack, "Polarization, Politics and Property Rights: Links between Inequality and Growth,” Public Choice, Vol. 111, No. 1-2, 2002, pp. 127-154.

\section{doi:10.1023/A:1015168000336}

[3] Business Software Alliance, “Annual BSA and IDC Global Software Piracy Study,” Available at: http://www.bsa.org.

[4] D. Leblang, "Property Rights, Democracy, and Economic Growth,” Political Research Quarterly, Vol. 49, No. 1, 1996, pp. 5-26. doi:10.1177/106591299604900102

[5] A. Goldsmith, "Democracy, Property Rights and Economic Growth,” Journal of Development Studies, Vol. 32, No. 2, 1995, pp. 157-174.

doi:10.1080/00220389508422409

[6] J. Svensson, "Investment, Property Rights and Political Instability: Theory and Evidence," European Economic Review, Vol. 42, No. 7, 1998, pp. 1317-1341. doi:10.1016/S0014-2921(97)00081-0

[7] W. Park and J. Ginarte, "Intellectual Property Rights and Economic Growth,” Contemporary Economic Policy, Vol. 15, No. 3, 1997, pp. 51-61. doi:10.1111/j.1465-7287.1997.tb00477.x

[8] C. Clague, P. Keefer, S. Knack and M. Olson, "Contract-Intensive Money: Contract Enforcement, Property Rights, and Economic Performance,” Journal of Economic Growth, Vol. 4, No. 2, 1999, pp. 185-211. doi:10.1023/A:1009854405184

[9] J. Markusen, "Contracts, Intellectual Property Rights, and Multinational Investment in Developing Countries," Journal of International Economics, Vol. 53, No. 1, 2001, pp. 189-204. doi:10.1016/S0022-1996(00)00058-1

[10] B. Javorcik, "The Composition of Foreign Direct Investment and Protection of Intellectual Property Rights: Evidence from Transition Economies," European Economic Review, Vol. 48, No. 1, 2004, pp. 39-62. doi:10.1016/S0014-2921(02)00257-X

[11] A. Glass and K. Saggi, "Intellectual Property Rights and Foreign Direct Investment," Journal of International Economics, Vol. 56, No. 2, 2002, pp. 387-410. doi:10.1016/S0022-1996(01)00117-9

[12] S. Claessens and L. Laeven, "Financial Development, Property Rights, and Growth," Journal of Finance, Vol. 58, No. 6, 2003, pp. 2401-2436. doi:10.1046/j.1540-6261.2003.00610.x

[13] R, Falvey, N. Foster and D. Greenaway, "Intellectual Property Rights and Economic Growth,” Review of Development Economics, Vol. 10, No. 4, 2006, pp. 700-719. doi:10.1111/j.1467-9361.2006.00343.x

[14] M. Boldrin and D. Levine, "Intellectual Property Rights and Economic Growth in the Long Run: A Model of Discover," American Economic Review: Papers and Proceedings, Vol. 99, No. 2, 2009, pp. 337-342.

[15] R. Barro, "Economic Growth in a Cross Section of Countries,” Quarterly Journal of Economics, Vol. 106, No. 2, 1991, pp. 407-444. doi:10.2307/2937943

[16] World Development Indicators, World Bank, Washington D.C., 2009.

[17] D. Kaufmann, A. Kraay, and M. Mastruzzi, "Governance Matters VI: Governance Indicators for 1996-2006," World Bank Policy Research Working Paper No. 4280, Washington D.C., World Bank, 2007. 
[18] S. Globerman and D. Shapiro, "Global Foreign Direct Investment Flows: The Role of Governance Infrastructure," World Development, Vol. 30, No. 11, 2002, pp. 1899-1919. doi:10.1016/S0305-750X(02)00110-9
[19] R. Levine, "Law, Endowments and Property Rights," Journal of Economic Perspectives, Vol. 19, No. 3, 2005, pp. 61-88. doi:10.1257/089533005774357842 